\title{
PENGGUNAAN SOFTWARE BEBAS (GNU/LINUX) DALAM PENDIDIKAN
}

Oleh: Gatot Pramono*)

\section{Abstrak}

Gerakan Open source yang muncul sebagai reaksi atas komersialisasi yang berlebihan dan pematenan perangkat lunak telah menjadi gerakan yang bersifat global. Gerakan ini bertujuan untuk menyebar luaskan perangkat lunak bebas (free software) kepada masyarakat dunia. Bebas(free) yang dimaksud di sini lebih menekankan kepada kebebasan dalam memodifikasi dan bukan pada harga (baca gratis). Gerakan open source memiliki kaitan yang sangat erat dengan sistem operasi GNU-Linux karena pada kenyataannya sebagian besar perangkat bebas lunak berjalan di atas platform Linux.

Tulisan ini akan mencoba menguraikan secara singkat munculnya gerakan open source, bagaimana para pengembang kemudian memaketkan dan menyebarkannya, serta aplikasiaplikasi apa saja yang bermanfaat bagi kita (khususnya untuk dunia pendidikan).

\section{Pengantar}

Sejak ilmu komputer berkembang (baca perangkat lunak) telah menjadi suatu kelaziman bahwa para pembuat (pengembang) perangkat lunak menjual produk mereka tanpa menyertakan kode sumber (source code). Hal ini berpijak pada pandangan yang menegaskan bahwa kode sumber merupakan hak kekayaan intelektual bagi sang pembuat perangkat lunak. Pembuat perangkat memiliki copy right atas kode sumber yang mereka ciptakan. Orang lain yang berusaha menjiplak atau mengubah kode sumber tanpa seijin dari si pembuat berarti telah melanggar hukum.

*) Drs. Gatot Pramono, M.Pet adalah staf Studio Multimedia Pustekkom Depdiknas. 
Perangkat lunak semacam ini disebut proprietary software. Dengan cara menjual proprietary software perusahaan pengembang perangkat lunak seperti Microsoft, Adode, Macromedia, atau Sun Microsystems menjadi raksasa-raksasa yang menguasai pasaran perangkat lunak dunia.

Perusahaan-perusahaan pembuat perangkat lunak berusaha sekuat tenaga untuk merahasiakan kode sumber produk mereka. Ironisnya, hal ini justru mendorong para cracker ${ }^{1}$ untuk berlomba-lomba membuka kerahasiaan perangkat lunak proprietary, membajaknya dan menjualnya kembali secara ilegal. Kita sering mendengar tentang (bahkan menggunakan) perangkat-perangkat lunak bajakan (pirate software).

Penggunaan perangkat lunak bajakan umumnya didorong oleh mahalnya harga proprietary software. Sebagai contoh bila harga satu paket Microsoft Windows 300 dollar AS saja, maka suatu perusahaan yang ingin menyediakan 20 komputer untuk karyawannya harus menyediakan anggaran minimal 40 juta rupiah hanya untuk sistem operasi komputer saja! Bagaimana bila perusahaan tersebut juga membutuhkan proprietary software lain yang mahal harganya? Berapa anggaran yang mesti disiapkan untuk biaya operasi perusahaan tersebut ? Mungkin ratusan juta atau bahkan milyaran rupiah. Di Indonesia, di mana penegakan hukum masih lemah, penggunaan perangkat lunak bajakan berlangsung secara terang-terangan walaupun secara resmi UU mengenai HAKI (Hak Kekayaan Intelektual) sejak tahun 2003 telah resmi berlaku.

Menggunakan perangkat lunak berarti kita telah melanggar hukum. Lalu bagaimana bila masyarakat membutuhkan suatu perangkat lunak yang penting (misalnya saja suatu pengolah kata) sementara harga perangkat lunak tersebut sangat mahal ? Tiadakah jalan keluar ? Di dunia ini ternyata selalu ada a few good men yang berfikir secara extra ordinary dan menentang arus. Nah, mari kita lihat perjalanan gerakan open source yang dilakukan oleh sebagian kecil orang-orang yang berpikir keluar dari pakemnya.

1) Cracker merupakan istilah bagi orang-orang yang berusaha untuk mengintip kerahasiaan perangkat lunak milik orang lain. Para pembuat virus komputer umumnya juga disebut cracker. Harap dibedakan antara cracker dan hacker. Bila cracker berkonotasi negatif maka hacker sebaliknya berkonotasi positif. 


\section{Gerakan Open Source}

Komersialisasi perangkat lunak secara berlebihan (baca meraup keuntungan sebanyak-banyaknya) oleh perusahaan-perusahaan raksasa akhirnya memunculkan reaksi dari kalangan ahli perangkat lunak (hacker ${ }^{2}$ ). Reaksi ini memunculkan apa yang disebut gerakan open source. Para pendukung gerakan ini berpandangan bahwa menjadi hak bagi para pembeli perangkat lunak untuk mengetahui kode sumber dari perangkat lunak yang dibelinya. Dengan mengetahui kode sumbernya mereka memiliki kesempatan untuk mengubah perangkat lunak yang mereka beli sesuai dengan kebutuhan mereka. Hal ini bisa dianalogikan dengan orang yang membeli mobil. Pembeli mobil punya hak untuk melihat mesin mobil, memperbaikinya bila rusak, atau memodifikasi mesin sekehendak hatinya. Dengan analogi ini maka pembeli proprietary software adalah seperti pembeli mobil yang tutup mesinnya dilas sehingga ia tak dapat melakukan apa-apa terhadap mobil yang telah ia beli kecuali pasrah terhadap apapun yang telah ditentukan oleh para pembuat mobil. Tentu saja sikap para hacker yang menyertakan kode sumber bagi perangkat lunak yang mereka ciptakan ini merupakan sikap menentang arus bagi umumnya perusahaan perangkat lunak yang justru mati-matian merahasiakan kode sumber perangkat lunak buatannya. Jika hak atas perangkat lunak yang dimiliki oleh para pembuat proprietary software disebut copy right, maka para pendukung open source menyebut hak untuk open source software sebagai copy left.

Gerakan open source (perangkat lunak bebas) ini sekilas memang tak lazim. Mereka menjual produk mereka dengan harga murah, bahkan banyak yang memberikan produk mereka secara gratis kepada khalayak. Yang lebih ekstrim lagi mereka mengijinkan (membiarkan) orang untuk mengubah perangkat lunak buatan mereka, bahkan mengijinkan orang untuk menjual perangkat lunak yang telah dimodifikasi. Gerakan yang telah mengglobal ini tak pelak menjadi

2) Hacker merupakan sebutan untuk orang-orang yang tergila-gila pada perangkat lunak dan mendalami cara kerjanya secara maksimal. Hacker biasanya berkonotasi positif. Pengembang perangkat lunak bebas (open source software atau free software) adalah para hacker. 
ancaman serius bagi para pemilik perusahaan pembuat proprietary software. Tak kurang dari Microsoft merasa bahwa ancaman paling serius bagi dominasi mereka adalah gerakan open source.

Berkat gerakan open source maka hari ini masyarakat dunia dapat menikmati dan menggunakan ribuan perangkat lunak yang murah dan gratis. Sebut saja perangkat lunak yang anda butuhkan, hampir semuanya tersedia gratis di internet. Mulai dari editor atau pengolah kata yang simpel, aplikasi perkantoran seperti Microsoft Office, pengolah gambar, bahasa pemrograman, data base sampai web server semuanya ada di internet. Dua situs utama yang menyediakan perangkat lunak gratis ini adalah www.sourceforce.net dan freshmeat.net

Mungkin anda bertanya-tanya apa untungnya bagi pengembang perangkat lunak bebas (open source) ini? Perlu anda catat bahwa mengembangkan suatu perangkat lunak merupakan pekerjaan berat dan sangat menyita waktu. Lalu apa motivasi mereka yang telah menghabiskan waktu dan sumber daya lainnya untuk mengembangkan perangkat lunak kemudian memberikannya secara gratis ? Jawaban untuk pertanyaan ini bisa beragam. Ada yang termotivasi semata karena sifat altruisme. Adalah hal yang mulia jika mereka dapat memberikan sesuatu yang bermanfaat bagi dan dibutuhkan oleh masyarakat. Ada yang terdorong oleh keinginan dan semangat untuk unjuk gigi bahwa mereka mampu membuat suatu perangkat lunak yang canggih. Motivasi ini biasanya merupakan suatu promosi terselubung. Ada lagi yang mengembangkan perangkat lunak bebas sebagi pancingan. Mereka mempublikasikan produk mereka yang bebas dan gratis tapi dengan fitur yang minim. Bila orang ingin mendapatkan produk serupa dengan fitur yang lengkap maka mereka harus membelinya. Ada pula yang mempublikasikan perangkat lunak bebas sebagai uji coba untuk produk komersial mereka. Ada 1 alasan lagi yang umumnya dimiliki para hacker. Seperti telah disebutkan dimuka bahwa mengembangkan perangkat lunak membutuhkan waktu yang lama. Pemeriksaan terhadap kesalahan-kesalahan pemrograman (disebut bug) sangat menyita waktu bagi para pengembang. Dengan mempublikasikan produk mereka sebagai open source berarti mereka memberikan kesempatan 
orang lain untuk memeriksa bug-bug yang ada serta turut membantu memperbaikinya. Dengan demikian penyempurnaan suatu perangkat lunak dapat dilakukan dalam waktu yang lebih singkat. Pada prakteknya pengembangan suatu perangkat lunak bebas memang melibatkan banyak orang.

Apapun alasan dari para pengembang perangkat lunak bebas yang jelas masyarakat dunia dapat menikmati perangkat-perangkat lunak yang murah atau gratis tetapi memiliki kualitas yang setara dengan proprietary software. Jadi perangkat lunak bebas tidaklah selalu berkonotasi mutu yang rendah.

Namun demikian ada satu kesalah pahaman yang mesti diluruskan. Perangkat lunak bebas lebih menekankan kepada kebebasan kepada para pemakainya dalam mengubah perangkat lunak dan bukan pada masalah harga. Jadi boleh-boleh saja perangkat lunak bebas dijual secara komersial dengan harga yang mahal sekalipun ! Richard Stallman sendiri sebagai dedengkot perangkat lunak bebas menegaskan bahwa : "Free Software doesn't mean zero dollar!" Untungnya memang banyak perangkat lunak bebas yang memang benar-benar gratis.

Anda mungkin juga bertanya-tanya siapa tokoh-tokoh yang menonjol dari gerakan open source ini dan mengapa open source sering dihubungkan dengan Linux? Richard Stallman- sang pendiri Free Software Foundation, Eric Raymond, Linus Thorvalds - sang pencipta Linux mungkin merupakan tokoh-tokoh yang menonjol. Tokoh-tokoh lain yang dapat disebut adalah Larry Wall- si pencipta bahasa Perl atau Rasmus Lerdorf- si pencipta bahasa PHP. Jika perangkat lunak bebas sering dihubungkan dengan Linux memang disebabkan oleh fakta bahwa sebagian besar perangkat lunak bebas berjalan di atas platform Linux. Memang ada pula perangkat lunak bebas yang berjalan pada Windows atau Mac, tapi dari segi kuantitas tidaklah sebanyak yang berjalan di Linux. Tentu saja hal ini memiliki riwayat tersendiri. Nah, mari kita lihat bagaimana perangkat lunak bebas dan Linux saling berkaitan satu sama lain. 


\section{Perangkat lunak bebas dan GNU-Linux}

Untuk melihat hubungan perangkat lunak bebas dan Linux mari kita lihat kurun waktu 20 atau 30 tahun kebelakang. Adalah Richard Stallman, seorang peneliti di Massachuset Institute Of Technology (MIT) , yang merasa gerah dengan komersialisasi berlebihan dan pematenan perangkat lunak. Institusi tempat ia bekerja pun tak luput dari kecenderungan ini. Terdorong untuk membuat perangkat lunak bebas (Free Software) dan ketidak cocokannya dengan kebijaksanaan MIT untuk mematenkan perangkat lunak, maka pada tahun 1980 an Stallman keluar dari MIT dan segera mendirikan suatu yayasan yang ia beri nama Free Software Foundation (FSF). Misi dari yayasan yang ia bentuk adalah menyebarkan perangkat-perangkat lunak bebas yang dapat dimanfaatkan oleh banyak orang. Seperti telah disebutkan dimuka perangkat lunak bebas atau free software menurut definisi dari Richard Stallman adalah menekankan pada kebebasan dimana kebebasan ini dapat diraih hanya bila kode sumbernya disertakan. Sekalipun Stallman tidak menyinggung masalah gratis sebagai faktor utama tetapi kenyataannya semua perangkat lunak yang dihasilkan FSF adalah gratis. Lalu dari mana FSF mendapatkan dana untuk menyokong misinya? Ini yang menarik; FSF memperoleh sumber dananya sematamata dari para donator (bahkan hingga sekarang) yang memiliki perhatian terhadap masalah perangkat lunak bebas.

Untuk mendukung misinya ini maka melalui FSF Stallman mendirikan suatu proyek yang ia beri nama GNU yang merupakan akronim rekursif dari GNU Not Unix. Ini merupakan cara bernada humor untuk memberi nama sesuatu. Banyak proyek-proyek dalam gerakan open source yang diberi nama dengan cara seperti ini, contoh PHP merupakan singkatan dari PHP Hypertext Preprocessor atau KDE merupakan KDE Desktop Environment. Mengenai KDE akan dibahas nanti.

Lalu apa hubungannya dengan Unix ? Nah bagi anda yang mungkin masih asing dengan Unix, Unix merupakan sistem operasi handal yang pertama kali muncul pada awal tahun 1970an, jauh sebelum DOS, Mac, apalagi Windows. Unix pertama kali dibuat oleh perusahaan 
telekomunikasi AT\&T di Amerika Serikat. Unix merupakan sistem operasi yang sejak awal didesain untuk mampu melakukan multitasking (beberapa proses dapat berjalan bersamaan) dan multiuser (beberapa pengguna berbeda, dengan ID masing-masing, dapat menggunakan komputer yang sama ). Unix juga merupakan sistem operasi yang sejak awal didesain untuk berjalan pada jaringan komputer. Karena kehandalannya banyak pakar komputer menyebut Unix sebagai The True Operating System. Unix banyak digunakan di lingkungan industri maupun penelitian. Sayangnya karena lebih banyak berjalan pada komputer besar Unix kurang dikenal oleh para pengguna komputer pribadi (PC). Tak heran bagi para pengguna PC Mac dan Windows jauh lebih populer. Unix sendiri dalam perjalanannya memiliki banyak varian. Salah satu varian Unix yang free adalah Free BSD. Ketika Stallman bekerja di MIT, Unix merupakan sistem operasi yang digunakannya dalam penelitian. Karena faktor kedekatan inilah maka ia kemudian merancang perangkat lunak bebas yang berjalan di atas platform Unix. Karena itu ia menamakan proyeknya sebagai Gnu Not Unix untuk menunjukkan bahwa proyeknya tak ada kaitannya dengan perusahaan pengembang atau vendor Unix.

Proyek GNU banyak menghasilkan perangkat-perangkat lunak bebas yang tidak hanya free tetapi juga berkualitas. Perangkat-perangkat lunak yang diproduksi pada awal proyek ini misalnya emacs, suatu editor dan IDE (Integrated Development Environment) bagi bahasa pemrograman yang sangat canggih. Kemudian produk lainnya yang terkenal adalah GCC (suatu compiler untuk bahasa C). Baik emacs dan GCC keduanya diakui secara luas sebagai perangkat lunak berkualitas dan bahkan mengalahkan perangkat lunak proprietary. Saat ini produk dari GNU sangat banyak dan semuanya berkualitas.

Sekalipun telah menghasilkan aplikasi-aplikasi hebat GNU masih bergantung kepada suatu sistem operasi yakni Unix. Ketergantungan

3) Kernel merupakan jantung suatu sistem operasi yang banyak menangani operasi low level seperti berhubungan dengan hardware. Untuk memanfaatkan sumber daya komputer pengguna komputer tidak berhubungan langsung dengan kernel melainkan dengan aplikasi perantara yang disebut utilities atau shell 
ini sesungguhnya hanya kepada kernel ${ }^{3}$ dari Unix dan bukan pada Unix secara keseluruhan. Proyek GNU bukannya tidak responsif terhadap kekurangan ini, mereka berinisiatif membuat kerne/ sendiri yang mereka sebut GNU/HURD. Sayangnya setelah lebih dari 20 tahun GNU/HURD belum juga berjalan stabil dan belum digunakan secara luas. Jadi GNU tetap tergantung pada Unix.

Saat GNU kekurangan suatu komponen penting dari suatu sistem operasi, yakni kernel, maka pada awal tahun 1990an muncullah Linus Thorvalds, saat itu masih mahasiswa pada Universitas Helsinki, dengan kernel ciptaannya. Linus membuat kernel sebenarnya hanya untuk hobi saja. Tetapi ketika ia mempublikasikannya di internet ternyata sambutan dari para hacker sangat besar. Para hacker ini kemudian membantu Linus menyempurnakan kernel ciptaannya. Maka kemudian jadilah suatu kernel sistem operasi yang dinamakan Linux. Linus dan para hacker lainnya membuat Linux berdasarkan standard yang disebut POSIX (Portable Operating System Interface). Standard POSIX merupakan standard yang juga digunakan oleh Unix, maka jadilah Linux kernel yang mirip dengan kernel Unix tetapi Linux bukan Unix karena ditulis dengan kode sumber yang berbeda dari Unix. Perlu digaris bawahi disini bahwa Linux hanyalah suatu kernel yang hanya merupakan salah satu komponen dari banyak komponen yang dimiliki suatu sistem operasi. Untuk menjadi suatu sistem operasi maka Linux memerlukan aplikasi-aplikasi lain yang biasanya disebut utilities. Aplikasi utilities dari GNU kemudian digunakan oleh Linus untuk menyempurnakan Linux. Jadi sinergi dari GNU dan Linux lah yang akhirnya menghasilkan sistem operasi Linux yang kita kenal sekarang ini. Karena kontribusi dari GNU sangat besar dalam perkembangan Linux maka Richard Stallmann bersikeras bahwa nama dari sistem operasi yang baru ini bukan Linux melainkan GNU-Linux. Sekalipun pendapat Stallmann benar adanya, orang-orang sering menyebut sistem operasi ini sebagai Linux saja. 


\section{Bagaimana GNU-Linux berbeda dari sistem operasi lainnya}

Untuk melihat bagaimana GNU-Linux berbeda dari sistem operasi lainnya kita lihat terlebih dahulu komponen-komponen apa saja yang membentuk suatu sistem operasi.

Suatu sistem operasi modern paling tidak memiliki 3 komponen utama yakni: kernel, utilities, dan desktop environment. Kernel seperti telah kita ketahui merupakan jantung dari suatu sistem operasi.Jika sistem operasi diibaratkan mobil maka kernel merupakan mesin dari mobil. Kernel mengatur hardware dan mengendalikan resources komputer secara keseluruhan. Kernel umumnya bekerja pada level bawah (lowlevel) dari suatu komputer. Karena bekerja pada low-level ini maka pengguna tidak berhubungan langsung dengan kernel. Pengguna berhubungan dengan kernel melalui suatu aplikasi yang sering disebut sebagai utilities. Pada Unix dan juga Linux utilities ini kadang-kadang disebut juga sebagai shell. Dengan pengibaratan mesin mobil, pengemudi mobil tidak berhubungan langsung dengan mesin mobil ketika akan menambah kecepatan, me-rem, atau mengganti transmisi melainkan dengan perantaraan pedal gas, pedal rem atau tongkat transmisi. Begitu pula pengguna komputer yang ingin mengakses suatu hardware, apakah itu harddisk atau printer, maka ia berhubungan dengan perantara yang dalam hal ini adalah utilities atau shell. Utilies dengan demikian merupakan komponen penting yang kedua pada suatu sistem operasi. Tanpa utilities pengguna akan mengalami kesulitan dalam menggunakan resource komputer secara optimal.

Dengan kedua komponen ini sebenarnya suatu sistem operasi sudah dapat bekerja dengan baik. Akan tetapi pengguna tidak akan dimanjakan dengan tampilan memikat seperti yang ditunjukkan kalau mereka menggunakan Mac atau Windows. Komponen yang ketiga yakni desktop environment merupakan tampilan dengan jendela (window) yang tidak saja mempercantik tampilan suatu sistem operasi tetapi dalam banyak hal banyak memudahkan pengguna dalam menggunakan sistem operasi tersebut. Sebagai contoh tanpa desktop environment pengguna 
yang akan meng copy suatu file harus menggunakan perintah yang diketikkan pada prompt komputer (dikenal sebagai command line atau perintah konsol). Dengan desktop environment, pengguna yang ingin melakukan hal serupa cukup melakukan klik dengan mouse pada ikon copy dan paste yang tersedia. Menggunakan komputer sangat mudah dengan bantuan suatu desktop environment.

Nah, kini kita lihat perbedaan Linux atau GNU-Linux dengan sistem operasi lainnya. Pada sistem operasi lain seperti Mac atau Windows ketiga komponen penting dari sistem operasi berasal dari satu pihak (satu perusahaan). Bagaimana halnya dengan GNU-Linux? Nah ini uniknya, ketiga komponen yang membentuk GNU-Linux berasal dari pihak-pihak yang berbeda. Seperti telah dijelaskan dimuka Linus dan teman-temannya hanya membuat kernel. Apa yang disebut Linux sesungguhnya hanyalah sebuah kernel. Komponen kedua yakni utilities berasal dari proyek GNU. Lalu darimana komponen ketiga yaitu desktop environment datang? Desktop environment pada GNU-Linux juga datang dari pihak lain. Ada 2 desktop environment utama dalam GNULinux yakni KDE dan GNOME, masing-masing dari proyek KDE dan proyek GNOME. Ketiga komponen ini dalam GNU-Linux semuanya merupakan perangkat lunak bebas dan gratis. Disinilah keunikan GNULinux, sistem operasi ini tidak dimiliki atau dikuasai satu tangan melainkan dimiliki dan diatur oleh banyak pihak. GNU-Linux merupakan milik komunitas internasional.

\section{KDE dan GNOME}

Proyek open source di GNU-Linux yang paling menonjol dalam menyediakan desktop environment adalah proyek KDE dan GNOME. Desktop KDE dan GNOME sejak awal memang bersaing ketat dalam memuaskan para pengguna GNU-Linux. Kedua proyek ini tidak hanya menghasilkan desktop environment saja tetapi juga aplikasi-aplikasi lain. Sebagai contoh KDE mengeluarkan web browser Konqueror, sementara GNOME juga mengeluarkan Nautilus sebagai saingan Konqueror. Awalnya memang KDE lebih menonjol dan unggul, terutama dalam hal keindahan tampilan. Tetapi setelah GNOME mengeluarkan deskop versi 2.0 keindahan GNOME tidak kalah dari KDE. Kedua 
desktop ini masing-masing memiliki penggemar yang fanatik.

Sejak awal KDE dan GNOME memang berbeda. Perbedaan ini tidak hanya karena pusat proyek yang berbeda benua, KDE berpusat di Eropa sementara GNOME berpusat di Amerika, tetapi dalam filosofi open source maupun tools yang digunakan juga berbeda.

KDE dikembangkan dengan menggunakan suatu tool (pustaka API) untuk bahasa $\mathrm{C}++$ yang disebut QT. Bagi para penganut open source yang fanatik penggunaan QT telah menimbulkan masalah. QT yang merupakan produk dari Trolltech, Norwegia, merupakan produk komersial yang tidak open source. Penggunaan perangkat lunak non open source untuk mengembangkan aplikasi open source bagi sebagian orang dianggap menyalahi prinsip-prinsip open source. Akan tetapi kenyataan menunjukkan bahwa KDE sejak awal memang telah memikat penggemar GNU-Linux. Perlu dicatat bahwa GNU-Linux pada awalnya tidak menyertakan desktop. Jadi kemunculan KDE dengan menghadirkan desktop yang indah di GNU-Linux merupakan suatu hadiah yang luar biasa bagi penggemar GNU-Linux. Sekalipun pada awalnya menghadirkan kontroversi tak dapat dipungkiri bahwa KDE merupakan desktop paling favorit di dunia (juga di Indonesia).

Kemunculan GNOME, tak dapat dipungkiri, merupakan reaksi dari kemunculan KDE yang bagi sebagian orang menimbulkan kontroversi. Jika pengembang KDE memilih perangkat lunak non open source maka pengembang GNOME berusaha tetap teguh pada azas-azas open source. Untuk itu pengembang GNOME memilih menggunakan tool GTK+ yang memang merupakan perangkat lunak bebas. Jika QT berbasis pada bahasa $\mathrm{C}++$ maka GTK+ berbasis pada the grand old language yakni bahasa $\mathrm{C}$. Semua aplikasi yang dihasilkan oleh GNOME tetap berdasarkan prinsip-prinsip open source. Memang ada perbedaan signifikan antara bahasa $\mathrm{C}$ dan bahasa $\mathrm{C}++$. Yang pertama belum mendukung object oriented programming sementara yang kedua , dianggap penerus dari $\mathrm{C}$, telah mendukung object-oriented programming. GNOME yang didukung oleh banyak hacker ternama ini perlahan-lahan (terutama sejak versi 2.0) mulai menyaingi dan 
mendekati KDE baik dalam kualitas aplikasinya maupun dalam keindahan tampilannya.

Apakah di GNU-Linux hanya ada KDE dan GNOME untuk desktop? Tentu saja tidak! Ada banyak desktop lainnya yang tak kalah menarik dibandingkan KDE dan GNOME. Sebut saja Blackbox, Fluxbox, IceWM, XFCE, dan masih banyak lagi yang lainnya. KDE dan GNOME berusaha menampilkan keindahan masing-masing, tetapi harga yang harus dibayar juga mahal. Kedua desktop ini (versi-versi terakhir) selain membutuhkan spesifikasi hardware yang canggih juga sangat boros dalam penggunaan resource dari komputer (baca memori). Di lain pihak desktop lain non KDE dan GNOME berusaha tampil minimalis. Desktopdesktop ini umumnya lebih menawarkan kecepatan dalam penggunaan daripada keindahan. Sekalipun dari segi keindahan desktop-desktop ini kalah dibandingkan KDE dan GNOME, tetapi desktop-desktop ini juga mempunyai penggemar tersendiri yang fanatik. Dalam menggunakan GNU-Linux pengguna memang bebas dalam menentukan pilihannya. Jika resource komputer yang dimlikinya terbatas seorang pengguna tidak harus menderita karena menggunakan KDE dan GNOME yang lambat, tapi dapat menggunakan desktop lain yang menawarkan kecepatan. Inilah uniknya dunia GNU-Linux ! la menawarkan pilihan yang sangat beragam tidak seperti di Mac atau Windows yang cenderung monoton.

\section{Distro}

Di dunia open source saat ini perkara mendapatkan sistem operasi mungkin perkara yang mudah. Bukankah dunia GNU-Linux telah menyediakan semua komponennya dengan gratis. Anda bisa mendapatkan kernel Linux di www.kernel.org, anda bisa mendapatkan utilitas-utilitas yang penting di www.gnu.org, kemudian anda juga dapat mendapatkan desktop-desktop seperti KDE di www.kde.org atau GNOME di www.gnome.org. Mestinya dengan mendapatkan komponenkomponen tersebut anda sudah dapat membangun suatu sistem operasi lengkap yang akan mendukung pekerjaan anda. Tetapi pekerjaan menggabungkan komponen-komponen tersebut tentulah bukan kerja untuk setiap orang, dibutuhkan suatu keahlian khusus untuk meramunya 
agar menjadi suatu sistem operasi yang dapat digunakan.

Lalu jika kita adalah orang-orang awam dalam komputer dan ingin mendapatkan sistem operasi Linux, bagaimana cara kita mendapatkan sistem operasi Linux? Nah disinilah distro berperan. Apakah distro itu? Distro merupakan suatu istilah bagi paket GNU-Linux yang sudah lengkap dan siap digunakan. Lalu siapa yang memaketkan distro ini?

Distro biasanya dipaketkan oleh suatu perusahaan, organisasi, komunitas atau bahkan perorangan. Dari para pembuat distro inilah kita (masyarakat) mendapatkan sistem operasi GNU-Linux yang sudah lengkap dan siap digunakan.

Dunia GNU-Linux menawarkan kebebasan dan keberagaman, demikian pula yang kita dapati pada distro. Sekalipun sumber dari distro sama, tetapi tampilan, kecanggihan, fungsionalitas, maupun cara mendapatkan masing-masing distro berbeda. Jika untuk kernel, utilitas maupun desktop kita bisa ambil dengan gratis, tidak semua distro bisa kita peroleh dengan gratis. Ada distro yang benar-benar free dan gratis seperti Debian, ada distro yang komersial dengan menyediakan pelayanan, tetapi juga menyediakannya secara gratis (tentu saja tanpa pelayanan) seperti Mandrake, atu ada pula distro yang benar-benar komersial seperti SuSE atau Red Hat. Ada distro yang menekankan pada kemampuan jaringan komputer seperti Red Hat, ada distro yang tampil dengan keindahan dan kemudahan desktopnya seperti Mandrake. Nah kita lihat distro-distro apa saja yang beredar dan bagaimana mereka berbeda antara satu dengan yang lainnya.

\section{Red Hat}

Red Hat merupakan salah satu distro yang tertua di dunia dan termasuk paling populer. Red Hat Inc, perusahaan pembuat Red Hat yang bermarkas di Amerika ini, telah mengeluarkan distro mereka sejak awal 1990 an. Sejak awal distro ini banyak digunakan untuk aplikasi jaringan. GNU-Linux pada awal kemunculannya banyak digunakan pada jaringan, karena kehandalannya dalam jaringan, tidak heran bila Red Hat saat ini merupakan distro yang digunakan pada banyak server di dunia. 
Menurut suatu survai Red Hat paling tidak menguasai $50 \%$ pasaran Linux di dunia. Di Indonesia, Red Hat termasuk distro yang paling banyak digunakan pada server.

Pada awalnya Red Hat menggunakan strategi yang unik dalam memasarkan produknya. Selain menyediakan versi komersial lengkap dengan pelayanannya, Red Hat juga menyediakan versi gratis yang dapat di download dari internet. Akan tetapi setelah Red Hat versi 9 (tahun 2003) , Red Hat tidak lagi mensupport distro yang gratis. Selanjutnya Red Hat hanya memproduksi produk komersial yang dinamakan RHEL (Red Hat Enterprise Linux). Red Hat memang terjun ke bisnis murni karena pasar Red Hat memang cukup besar.

Sikap Red Hat di atas tentu saja mengecewakan penggemarnya yang banyak di seantero dunia. Tetapi Red Hat tidak meninggalkan begitu saja komunitas open source. Sebagai pengganti Red Hat yang gratis Red Hat menyokong suatu distro baru yang dinamakan Fedora Core. Sekalipun Red Hat tidak mendukung secara resmi proyek Fedora akan tetapi Red Hat berjanji untuk tetap memberikan dukungan pada Fedora Core. Para penggemar Linux yang terlanjur jatuh hati pada Red Hat dapat beralih pada Fedora Core.

\section{SuSE}

SUSE merupakan distro Linux yang berbasis di Eropa ( Jerman). Mungkin karena sama-sama dari Eropa distro ini menggunakan desktop KDE sebagai desktop defaultnya, apalagi kenyataannya banyak pegawai SuSE yang turut $\mathrm{m}$ e $\mathrm{ng}$ e $\mathrm{mb}$ a n g k a desktop KDE.

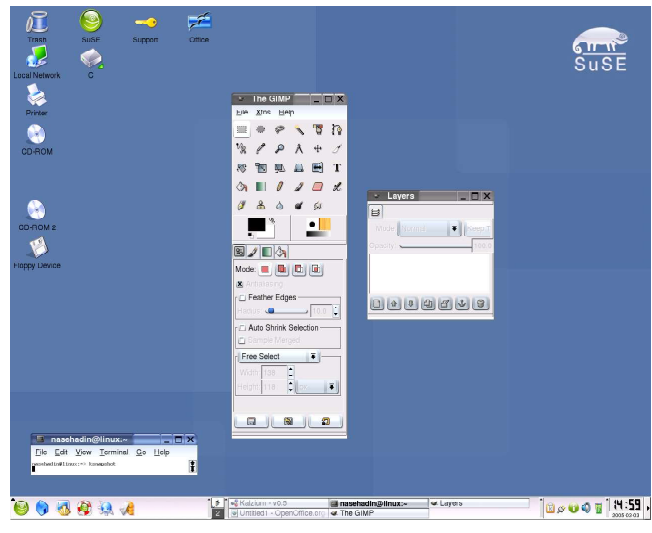

Gambar 1. Tampilan desktop 
Berbeda dengan Red Hat, sejak awal SuSE hanya menyediakan produk komersial. Distro SuSE memang sepertinya memang diproduksi untuk memuaskan para penggemar desktop yang menginginkan tampilan desktop yang indah. SuSE memang hadir untuk memuaskan para penggemarnya, desktop milik SuSE memang indah.

Disamping itu SuSE juga menyediakan sejumlah kemudahan bagi penggunanya. Linux pada awalnya memang bukan sistem opersai yang userfriendly seperti Windows. SuSE lah salah satu pelopor yang memberikan kemudahan-kemudahan seperti yang diberikan Windows. Perlu anda ketahui hal yang membuat para pemula malas menggunakan Linux adalah masalah instalasi software yang rumit dan tidak user friendly. Untuk memudahkan pengguna dalam menginstalasi software SUSE menyediakan suatu tool yang diberi nama YaST. Tool ini merupakan salah satu andalan SuSE.

Setelah lama berjaya di Eropa, tahun 2004 lalu, SuSE diakusisi oleh Novell, salah satu raksasa industri software di Amerika.

\section{Mandrake}

Dalam hal kemudahan yang ditawarkan oleh suatu distro, nama Mandrake mungkin yang pertama kali muncul dalam benak orang. Mandrake, distro buatan Perancis, memang sangat terkenal dalam hal kemudahannya. Ditambah dengan keindahan tampilan dan kemampuannya dalam mengenali banyak hardware, jadilah Mandrake salah satu distro yang paling favorit dan banyak digemari orang. Di Indonesia, menurut survei majalah Info Linux, Mandrake berkali-kali terpilih sebagai distro yang paling favorit. Menurut hemat penulis yang juga pernah menggunakan Mandrake, menggunakan Mandrake sangat mudah dan nyaman, senyaman kita menggunakan Windows. Jika anda adalah newbie ${ }^{4}$ dan ingin mencoba Linux maka Mandrake mungkin adalah pilihan yang tepat untuk anda.

4) Newbie adalah suatu istilah yang digunakan untuk pemula dalam menggunakan software. 
Seperti halnya SuSE, Mandrake juga banyak menyumbangkan pegawainya untuk mengembangkan KDE, maka tak heran bila distro ini juga menggunakan KDE sebagai desktop defaultnya.

\section{Debian}

Anda ingin mencoba distro yang benar-benar free dan tidak dimiliki atau dikuasai oleh suatu perusahaan tertentu ? Debian barangkali merupakan pilihan anda. Distro yang mungkin tertua diantara distrodistro yang masih eksis ini memang unik. Debian tidak dimiliki oleh suatu perusahaan tertentu tetapi dimiliki oleh komunitas open source internasional. Kurang lebih ada 1000 orang yang mengembangkan distro ini. Hebatnya lagi semuanya diorganisir melalui internet. Distro ini benarbenar free baik dari segi harga alias gratis maupun free dalam arti orang bebas menggunakan dan memodifikasinya. Untuk mendapatkan distro ini anda dapat mendownloadnya dari situs Debian di www.debian.org. Anda tidak akan dikenakan biaya apapun. Anda bahkan boleh menjual distro ini sesuka hati anda. Luar biasa bukan. Yang luar biasa lagi seluruh developernya tidak ada yang digaji; jadi semuanya merupakan kerja suka rela. Keuntungan bagi developernya adalah reputasi yang diperoleh karena nama besar Debian.

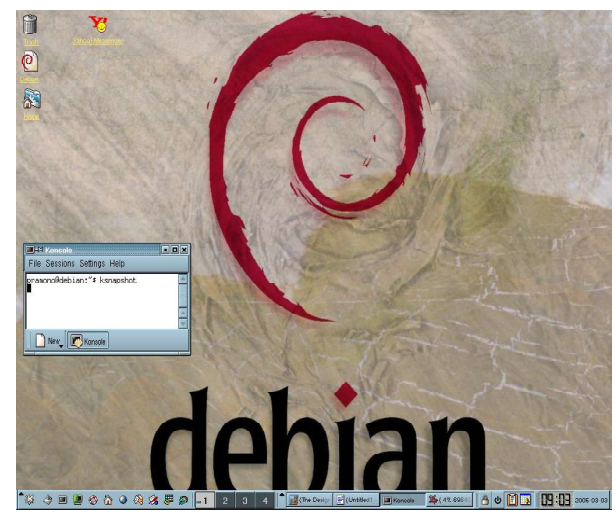

Gambar 3.

Tampilan KDE 2.2 di atas Debian GNU-Linux 3.0 
Dipandang dari filosofi open source, Debian mungkin distro yang paling orthodoks. Debian adalah satu-satunya distro yang mendapat dukungan dari FSF. Bahkan Richard Stallman berujar bahwa hanya Debian satusatunya distro yang benar-benar menerapkan prinsip-prinsip free software. Debian pula satu-satunya yang mencantumkan label GNULinux di belakang namanya. Jadi nama resminya adalah Debian GNULinux. Distro-distro yang lain hanya mencantumkan Linux, tanpa GNU, sebagai contoh Red Hat Linux atau Mandrake Linux.

Salah satu keunggulan dari Debian adalah manajemen paketnya. Semua paket software yang digunakan untuk Debian memiliki ekstension .deb. Pada hampir semua software yang dikembangkan oleh komunitas open source biasanya selalu tersedia paket khusus untuk Debian. Untuk meng-install maupun meng-uninstall suatu paket software Debian menyediakan suatu tool yang disebut apt-get. Para pakar Linux banyak yang berpendapat bahwa apt-get ini merupakan tool instalasi terbaik diantara tool-tool lain yang sejenis.

Sebagai suatu distro, Debian telah banyak menurunkan distro lain seperti Linspire atau Knoppix.

Kelebihan lain adalah distro Debian sangat stabil; artinya distro ini jarang mengalami crash atau hang. Tetapi kelebihan dalam masalah ini juga dipandang sebagai suatu kelemahan dari sisi lain. Karena sangat mementingkan kestabilan para developer Debian dalam versi resminya hanya memaketkan software-software versi lama. Jadi jika distro-distro lain berlomba-lomba memanjakan penggunanya dengan softwaresoftware versi terbaru, pengguna Debian harus rela berpuas diri dengan software-software versi yang lebih lama. Sebagai contoh ketika distrodistro lain sudah menggunakan KDE versi 3.x atau GNOME versi 2.x, Debian cukup berpuas diri dengan KDE versi 2.x atau GNOME versi 1.x. Padahal perbedaan keindahan dan fungsionalitas GNOME versi 1.x dan 2.x cukup jauh.

Bahkan ketika distro lain sudah mencapai versi 9.x atau bahkan 10.x,

5) Geek adalah istilah untuk para maniak komputer. 
Debian baru mencapai versi 3.x. Versi terakhir Debian adalah versi 3.0 yang sering juga disebut Debian Woody.

Kelemahan lainnya, Debian sepertinya hanya cocok untuk para ${ }^{5}$ yang suka mengoprek-oprek software. Pengguna awam mungkin sedikit kerepotan dalam menggunakan Debian.Umumnya para pengguna Debian adalah para akademisi di perguruan tinggi. Perusahaan atau pengguna awam jarang yang menggunakan distro ini.

\section{Distro-distro lainnya}

Masih ada distro lainnya? Tentu saja ! Sekarang kurang lebih 100 distro yang beredar. Ada yang besar, ada yang kecil, ada yang komplek, ada pula yang sederhana. Ada yang dibuat perusahaan besar, organisasi, bahkan ada yang dibuat oleh perorangan. Tentu saja diantara distrodistro ada yang menonjol, ada pula yang sekedar numpang lewat. Kita coba simak distro-distro lainnya yang menonjol. Slackware mungkin nama yanglayak untuk diketengahkan pertama kali. Distro tua termasuk salah satu distro besar yang menonjol. Keunikannya distro ini merupakan distro yang paling mirip dengan Unix. Berikutnya adalah Linspire dan Xandros. Kedua distro ini selain mencoba untuk tampil indah juga berusaha memberikan kemudahan bagi penggunanya seperti kemudahan yang diberikan Windows. Linspire (dahulu Lindows) merupakan salah satu diantara puluhan distro yang diturunkan dari Debian. Sayangnya baik Lispire maupun Xandros tidak menyediakan versi yang gratis. Untuk mendapatkannya kita mesti membayar. Berikutnya adalah distro yang unik yaitu Knoppix. Knoppix merupakan distro turunan dari Debian. Untuk menjalankan Knoppix kita tidak perlu menginstallnya, cukup kita jalankan dari CD drive. Unik kan ? Knoppix sangat berguna bagi orang yang sekedar ingin tahu Linux tanpa harus mengorbankan space pada hardware untuk menginstall Linux. Distro yang baru tapi tak boleh diremehkan adalah JDS (Java Desktop System). JDS merupakan distro buatan salah satu raksasa industri komputer, Sun Microsystem. JDS merupakan kerja sama antara Sun dengan SuSE. Distro ini sudah mengintegrasikan bahasa Java (juga buatan Sun) sehingga bagi para penggemar Java distro ini tentulah sangat 
menyenangkan. Nama besar Sun nampaknya akan berpengaruh besar bagi peredaran JDS. Sayangnya JDS ini juga produk komersial. Ada pula Fedora Core yang merupakan pengganti Red Hat bagi komunitas open source. Sekalipun masih baru distro ini cukup melejit namanya lantaran para penggemar Red Hat banyak yang beralih ke distro ini. Distro-distro lain yang layak disebut adalah Gentoo, Lycoris, Lorma Linux, DSL (Damn Small Linux).

\section{Aplikasi-aplikasi di Linux}

Nah, sekarang dengan mendapatkan distro, baik membelinya, mendownload dari internet atau mengkopi dari teman, kita sudah dapat menggunakan suatu sistem operasi lengkap sebagaimana Windows atau Mac. Namun kita mungkin masih ragu, aplikasi-aplikasi apa saja yang ada di Linux? Adakah aplikasi yang sepadan seperti aplikasi yang berjalan di Windows? Jangan khawatir, hampir semua aplikasi yang berjalan di Windows ada padanan dan tandingannya. Mari kita lihat bersama.

\section{Aplikasi perkantoran (office)}

Sebagai pekerja di kantor mungkin kebutuhan utama anda adalah aplikasi pengolah kata atau spread sheet atau presentasi. Di dalam Windows aplikasi-aplikasi ini di bundel dalam suatu aplikasi yang disebut Microsoft Office. Adakah aplikasi semacam ini di Linux ? Anda tak perlu ragu-ragu untuk menggunakan Linux jika yang anda butuhkan adalah aplikasi office. Hampir semua distro Linux selalu menyertakan suatu aplikasi yang bernama Open Office sebagai aplikasi office defaultnya. Dulu aplikasi ini bernama Star Office yang dikembangkan oleh Sun Microsystem dan dilempar ke publik sebagai software open source dan gratis. Kemudian Sun mengubah lisensi Star Office menjadi produk komersial, namun sebagai gantinya Sun mendukung proyek Open Office sebagai pengganti Star Office. Tentu saja Open Office ini merupakan perangkat lunak bebas dan gratis lagi.

Bagaimana performanya? Satu jawaban yang pasti Open Office tidak kalah dari Microsoft Windows, bahkan dapat menyamainya ! Open Office writer yang merupakan tandingan dari Microsoft Word dapat membuka 
dokumen dalam format Word dan juga dapat menyimpan dokumen dalam format Word, selain tentu saja Open Office writer punya format tersendiri yang mempunyai ekstension sxw. Open Office Calc merupakan tandingan Excel dan Open Office Impress merupakan tandingan Power Point. Jelas dengan menggunakan Linux anda tak perlu khawatir lagi mengenai tugas harian anda yang banyak membutuhkan aplikasi office.

Cuma itu ? Tentu saja tidak ! Ada lagi yang lain. Proyek KDE menelurkan Koffice dan proyek GNOME menelurkan Abiword sebagai tandingan Word dan Gnumeric sebagai tandingan Excel. Anda tinggal pilih saja mana yang anda sukai. Sekalipun banyak pilihan aplikasi office di Linux, sejauh ini tampaknya memang Open Office yang lebih unggul.

Oh ya sebelum lupa, untuk menjaga konsistensi dengan tulisan ini, penulis menyelesaikan tulisan ini menggunakan Open Office yang berjalan di atas Debian Linux versi 3.0.

\section{Aplikasi Pengolah Gambar}

Anda yang sering melukis pada komputer pun tak perlu khawatir. Proyek Gnome sejak lama telah mengeluarkan suatu pengolah gambar yang hampir setara dengan Adobe Photoshop, pengolah gambar professional yang berjalan di Windows. Pengolah gambar versi Linux ini disebut GIMP(www.gimp.org). GIMP merupakan akronim dari GNU Image Manipulation Program. Seperti Photoshop, GIMP juga menghasilkan gambar dalam format-format gambar yang populer seperti JPG, GIFF, PNG dan format-format lain. GIMP bahkan dapat digunakan untuk membuat animasi. Perlu anda ketahui beberapa perusahaan perfilman di Hollywood telah memanfaatkan GIMP untuk produksi film animasi mereka.

Jika di Windows kita mengenal Freehand, pengolah gambar berbasis vektor, maka di Linux pun kita menemukan aplikasi serupa seperti Karbon-14 yang merupakan produk dari proyek KDE dan Sodipodi. 
Bahkan jika anda ingin mendapatkan gambar 3 dimensi, anda bisa mendapatkannya. Maya dan POVRAY adalah beberapa contoh pengolah gambar 3 dimensi di Linux.

\section{Aplikasi Multimedia}

Anda ingin mengedit suara(sound) di Linux ? Sekarang telah tersedia Audacity yang ampuh digunakan untuk mengedit suara dan menambahkan effek-effek tertentu. Aplikasi ini juga menyediakan format yang lengkap mulai dari WAV, MP3, AU sampai format baru yang muncul dari komunitas Open Office yaitu OGG.

Untuk mengedit file video pun kebutuhan anda telah terpenuhi. Kino merupakan aplikasi pengolah file video di GNU Linux.

\section{Aplikasi Internet}

Aplikasi untuk internet di Linux rasanya sudah tak perlu lagi diragukan. Untuk browser ada begitu banyak pilihan sehingga jangan-jangan anda sendiri bingung untuk memilih mana yang paling baik. Proyek KDE sejak dulu telah menelurkan Konqueror yang tidak hanya berfungsi sebagai browser tetapi juga file explorer, PDF viewer bahkan image viewer. Hebat khan ! Proyek Gnome juga tak mau kalah, Nautilus adalah bowser andalannya. Yayasan Mozilla sejak lama juga telah memproduksi browser andalannya yakni Mozilla. Aplikasi yang dibuat berdasarkan Netscape ini pada beberapa distro bahkan menjadi browser default. Ada pula Opera versi Linux. Produk dari Norwegia bahkan di klaim sebagai browser tercepat di dunia. Baru-baru ini yayayan Mozilla bahkan telah merilis FireFox yang dengan cepat menggeser popularitas Explorer dari Microsoft. Nah, tadi daftar browser-browser raksasa. Di Linux andapun bisa menemukan browser kelas ringan seperti Dillo. Bahkan kalau kecepatan akses internet anda lambat dan anda hanya ingin melihat sitesite yang lebih banyak berisi teks, maka anda dapat menggunakan Links suatu browser yang hanya menampilkan teks. Tentu browser semacam ini bergerak lebih cepat dibandingkan raksasa-raksasa yang diesbut di atas. 
Tadi untuk browser, bagaimana aplikasi pada sisi server. Wah yang ini nampaknya mengungguli windows. Web server Apache, yang tersohor sebagai web server yang paling banyak digunakan didunia, berjalan pula di Linux. Bahkan menurut survai dari netcraft sebagian besar Apache berjalan di Linux. Untuk bahasa pemrograman pada sisi server pun PHP bekerja dengan baik. Bahkan ada jargon di Linux yaitu LAMP yang merupakan akronim Linux, Apache, MySQL dan PHP. Arti dari LAMP adalah penggunaan Apache, MySQL (database yang sangat populer di kalangan komunitas open source) dan PHP paling banyak digunakan di atas platform Linux. Perlu juga anda ketahui bahwa Apache dan PHP pun merupakan aplikasi open source. Jika anda ingin membangun aplikasi internet maka semua yang anda butuhkan tersedia gratis.

\section{Aplikasi Untuk Pendidikan}

Anda menginginkan aplikasi pendidikan ? Jangan kuatir ! Rasanya aplikasi pendidikan di GNU-Linux terlalu banyak untuk disebut satupersatu. Berikut ini adalah beberapa diantaranya: Chemtool adalah aplikasi untuk menggambar molekul, Elem - tabel periodik unsur kimia, Convert - aplikasi untuk mengkonversi satuan-satuan dalam fisika, Dr Geo - aplikasi untuk geometri, Geg - aplikasi untuk menggambarkan fungsi matematika, Kstars - aplikasi untuk melihat benda-benda luar angkasa yang sangat menarik. Sayangnya semua aplikasi ini masih dalam bahasa Inggris. Tetapi jika kita ingin menerjemahkannya ke dalam bahasa Indonesia kita bisa saja bergabung dengan komunitas yang mengembangkan aplikasi-aplikasi tersebut dan membantu menerjemahkannya ke dalam bahasa Indonesia.

\section{Kelemahan Linux}

Sedari tadi kita membicarakan segala kelebihan Linux, tentu saja tidak seimbang bila kita tidak mengulas juga kelemahan-kelemahannya. Tidak seperti Mac atau Windows yang sedari awal memang dirancang untuk memberikan kemudahan bagi penggunanya terutama pengguna awam yang tidak tahu seluk beluk komputer, Linux sebaliknya sejak awal dibuat sepertinya untuk orang-orang yang senang menggeluti komputer (geek). Linux pada awalnya tidak menawarkan kemudahan (userfriendlines) 
sehingga pengguna awam akan enggan untuk mencoba Linux. Contoh satu hal yang penting tetapi terabaikan dari segi kemudahan pada Linux adalah masalah instalasi software. Bagi pengguna awam atau para newbie menginstalasi software di Linux menjadi sesuatu yang menakutkan. Bagaimana tidak menakutkan bila untuk menginstall software pengguna harus mengetik perintah-perintah pada konsol. Para pengembang software di Linux bukan tak menyadari hal ini, mereka kemudian mengembangkan beberapa tool yang memudahkan instalasi software seperti RPM (Red Hat Package Manager) atau APT (Advance Package Tool) pada distro Debian. Tetapi ini juga masih menyulitkan bagi pengguna awam (apalagi bila mereka selama ini sudah dimanjakan oleh Windows). Beberapa distro seperti SuSE atau Mandrake memang telah memberikan kemudahan dalam menginstal atau menghapus software. Beberapa distro seperti Linspire bahkan menawarkan kemudahan seperti di Windows, artinya pengguna cukup melakukan click pada mouse untuk menginstall software.

Masih berhubungan dengan instalasi software, satu hal lain yang mengganggu pada Linux adalah masalah dependensi. Dalam hal ini jika kita ingin menginstall suatu paket $A$ dan ternyata paket $A$ memerlukan paket $B$, dan ternyata pula paket $B$ memerlukan paket $C$, maka mulamula kita harus menginstal paket $C$, kemudian paket $B$ baru kita bisa menginstall paket A. Rumit bukan ? Ini dapat menjadikan pengguna awam mengalami mimpi buruk jika menggunakan Linux. Tool APT pada distro Debian memang menawarkan kemudahan dalam masalah dependensi ini, artinya jika kita ingin menginstall paket A maka cukup paket itu saja yang kita install. Perkara paket tersebut memerlukan 1000 paket lainnya maka APT lah yang mengaturnya, kita tak perlu repotrepot. Masalah dependensi ini walaupun merepotkan sebenarnya punya tujuan yang baik yaitu untuk mnghemat dalam masalah penggunaan sumber daya komputer. Jadi bila ada beberapa paket yang harus tergantung pada paket $\mathrm{C}$, misalnya, maka kita cukup sekali menginstall paket $\mathrm{C}$ untuk sekian banyak paket yang membutuhkan paket $\mathrm{C}$.

Kelemahan atau mungkin kelebihan (tergantung dari mana kita memandang) lain dari Linux adalah banyaknya istilah-istilah teknis yang 
membuat pemula akan ciut nyalinya. Memang hal ini tak terhindarkan mengingat Linux merupakan OS yang menggunakan standard yang sama dengan UNIX. UNIX sendiri sejak awal memang dibuat bukan untuk pengguna komputer probadi (PC). Pengguna yang terbiasa dimanjakan oleh Mac atau Windows mungkin hampir-hampir tak pernah lagi berhubungan dengan prompt untuk memasukkan perintah-perintah yang diperlukan. Hal ini berbeda di Linux dimana pengguna sesekali bahkan sering kali (tergantung kebutuhan) berhubungan dengan perintah-perintah melalui prompt ( di Linux hal ini sering disebut perintah konsol). Linux memang seolah-olah menuntut penggunanya untuk menguasai hal-hal yang teknis, walaupun sesungguhnya tuntutan semacam ini tergantung pada pekerjaan dari si pengguna. Jika ia hanya berurusan dengan aplikasi semacam pengolah kata rasa-rasanya ia tak perlu untuk menguasai hal-hal yang teknis. Lain halnya jika ia seorang administrator jaringan atau senang mendalami software maka penguasaan hal-hal teknis sangatlah diperlukan.

Keberagaman di Linux di satu sisi memberikan kebebasan tapi di sisi lain juga menimbulkan kebingungan. Sekalipun misalnya Red Hat, SuSE atau Debian menggunakan kernel maupun aplikasi desktop yang sama, perbedaan diantara mereka sering tak terhindarkan. Contoh yang jelas adalah masalah manajemen paket. Baik Red Hat, SuSE maupun Debian atau distro-distro yang lain sering kali menggunakan paket manajemen yang berbeda-beda. Hal ini tentulah cukup memusingkan bagi para pengguna baru. Dalam pengenalan hardware pun antara distro yang satu dengan distro yang lainnya berbeda. Sebagai contoh ada modem internal yang dikenali oleh suatu distro tetapi tidak dikenal oleh distro yang lain. Jika kebetulan kita menggunakan distro yang tak mengenal hardware yang ada di komputer kita maka biasanya kita mesti repotrepot mencari drive yang diperlukan di internet. Kita mesti mendownload drive tersebut kemudian mesti membaca manual bagaimana menginstall drive tersebut dalam komputer kita. Ini pun dengan catatan kita dapat menemukan drive tersebut di internet, bagaimana bila tidak ? Ya kita mesti bertanya kepada orang yang tahu. Repot bukan! Perbedaan yang lain ada distro yang tidak menyertakan format-format software tertentu karena alasan paten. Misal Red Hat 9 (Red Hat versi terakhir sebelum 
berpindah menjadi Red Hat Enterprise) tidak mensupport file -file MP3. Untuk memainkan lagu-lagu berformat MP3 di Red Hat 9 lagi-lagi kita mesti sibuk mencari drive nya di internet. Tentu saja masih banyak perbedaan-perbedaan lain antara distro satu dengan lainnya. Hanya pengalaman dan jam terbang dalam penguasaan Linux yang membuat seseorang terbiasa berpindah dari distro satu ke distro lainnya.

Perbedaan-perbedaan di atas tentu saja sering membuat orang bingung dalam memilih distro apa yang mesti digunakan. Jawabannya ya tergantung pada kebutuhan kita dan seberapa banyak anggaran kita untuk software. Jika kita adalah pengguna biasa yang sering menggunakan aplikasi-aplikasi desktop maka pilihlah distro yang sudah terbukti bagus untuk aplikasi desktop. Contoh yang jelas adalah Mandrake atau SuSE. Jika kita mempunyai anggaran lebih mungkin JDS adalah pilihan lain yang cocok. Jika anggaran terbatas dan kita ingin menggunakan distro yang benar-benar gratis, maka pilihan terbaik adalah Debian. Semua pilihan tentu saja memiliki konsekuensi masingmasing.

\section{Masa Depan Linux}

Open source dan gratis tentu saja bukan jaminan bahwa Linux akan menjadi Sistem Operasi yang dominan dan mengungguli so-so yang lain. Menggeser Windows yang telah puluhan tahun mendominasi SO di dunia tentu bukan usaha setahun dua tahun. Apalagi jika mengingat kurang lebih $90 \%$ komputer pribadi di dunia menggunakan Windows sebagai sistem operasinya. Menyangkut masalah teknologi, tak mudah untuk membuat orang segera berpaling pada suatu teknologi baru sementara mereka telah terbiasa dengan teknologi lama. Apalagi bagi orang awam butuh waktu untuk mempelajari teknologi baru seperti Linux, dan tidak semua orang bersedia melakukanya ! Disamping itu seperti telah diuraikan di muka Linux memiliki kelemahan-kelemahan yang membuat orang takut untuk mencobanya.

Tak ada masa depan bagi Linux ? Tentu saja ada ! Dunia ini begitu dinamis dan tak mudah dikontrol oleh satu pihak. Microsoft yang begitu 
mendominasi dunia komputer pribadi dan terkesan sangat komersial pada akhirnya memunculkan gerakan semacam open source yang bertujuan memberikan alternatif lain di luar Microsoft dengan Windowsnya. Jika gerakan open source semacam ini terus menerus mempopulerkan alternatif-alternatif lain yang tidak kalah bagusnya dibandingkan Windows bukan tidak mungkin suatu saat dominasi Windows pun akan runtuh. Sinyal menguatnya dukungan terhadap gerakan open source mulai terasa di berbagai belahan dunia. Eropa (khususnya Jerman) mungkin merupakan salah satu di mana gerakan open source tumbuh dengan subur. Beberapa bagian lain dunia juga tak mau ketinggalan termasuk Asia. Sayangnya Indonesia sepertinya lagi-lagi tertinggal dibandingkan negara-negara lain, bahkan dengan negara-negara Asia Tenggara. Vietnam, yang notabene pembangunannya lebih tertinggal dibandingkan dengan Indonesia, telah mengeluarkan kebijakan bahwa semua komputer bagi dunia pendidikan harus berisi perangkat lunak open source. Bagaimana dengan pemerintah Indonesia ? Ada kebijakan semacam itu ? Gerakan IGOS (Indonesia Go Open Source) sepertinya kurang gaungnya dan tak dikenal masyarakat.

Satu faktor lagi yang mendorong orang berpaling pada perangkat lunak bebas adalah usaha beberapa vendor perangkat lunak terkenal yang membuat suatu aliansi bernama BSA (Business Software Alliance). Aliansi ini berusaha untuk melindungi perangkat lunak buatan mereka dari pembajakan dengan cara menekan banyak negara untuk menerapkan HAKI dan menerapkan sangsi yang keras bagi pembajak, penjual maupun pemakai perangkat lunak bajakan. Penerapan sangsi ini mulai terasa di negara-negara maju seperti di negara-negara Eropa. Penerapan yang keras terhadap para pengguna perangkat lunak bajakan ini sebenarnya justru memberikan dampak positif. Orang kemudian justru berpaling pada perangkat-perangkat lunak bebas sehingga mereka terhindar dari resiko menerima hukuman atas pelanggaran HAKI.

Satu hal lagi yang sering dipertanyakan oleh mereka yang masih ragu dengan Linux : Mampukah Linux mempertahankan perangkat lunak bebas (dalam arti bisa didapatkan dengan gratis atau dengan harga yang murah)? Bukankah Red Hat adalah contoh nyata bagaimana akhirnya 
berpaling menjadi distro yang sepenuhnya komersial ? Semua itu benar adanya, tetapi perlu diingat bahwa dunia open source adalah dunia yang penuh pilihan. Anda tak suka dengan Red Hat yang komersial anda bisa pilih distro yang lain. Contohnya sudah jelas. Begitu Red Hat berubah menjadi distro komersial segera muncul distro seperti Fedora Core yang gratis. Jadi rasa-rasanya kita tak perlu khawatir menggunakan Linux. Ketika ada suatu produk yang dilempar sebagai produk komersial maka akan ada orang lain yang membuat produk serupa yang gratis. Bukankah dunia open source adalah dunia keterbukaan dimana semua kode-kode perangkat lunak yang beredar diketahui oleh semua orang. Jadi semua orang dapat mempelajari,membuat, bahkan menjual perangkat lunak. Sekalipun nanti seandainya Linus Thorvalds mengkomersilkan kernel linux nya maka pasti akan ada orang lain yang akan membuat kernel tandingan yang bisa digunakan oleh banyak orang.

Perbedaan yang menyolok antara dunia open source dengan dunia software proprietary adalah dunia open source memberikan kebebasan ; anda ingin mendapat dukungan ketika membeli suatu software maka belilah produk yang komersial, jika anda tak mampu membelinya carilah software serupa yang gratis. Sementara dunia software proprietary hanya menawarkan satu hal: belilah produk kami secara legal. Tanpa source code nya tentu saja.

\section{Penutup}

Kemunculan sistem operasi GNU-Linux dan komunitas open source selayaknya kita sambut dengan gembira. Dengan GNU-Linux kita tidak saja mendapatkan perangkat lunak yang gratis atau dengan harga yang murah tetapi juga mendapatkan kesempatan untuk mempelajarinya (dengan melihat source codenya) sehingga perkembangan ilmu komputer (software engineering) di Indonesia akan meningkat dengan pesat. Ketergantungan terhadap perangkat lunak proprietary yang mahal akan berkurang. Kita bahkan bisa mengembangkan perangkat lunak yang sesuai dengan kebutuhan kita tanpa harus dihantui masalah hak cipta karena kita menggunakan produk bajakan. Keuntungan mengunakan free software akan semakin signifikan bila mengingat 
keadaan ekonomi bangsa kita yang belum pulih. Berbicara mengenai dunia pendidikan penggunaan free software jelas akan memberikan dampak yang sangat baik. Tidak saja kita bisa mendapatkannya secara gratis atau murah, tetapi juga memacu anak-anak didik kita untuk mengembangkan software mereka sendiri.

Pemasyarakatan GNU-Linux tentu saja membutuhkan kerja keras. Bagi mereka yang berkecimpung di dunia pendidikan mestinya merasa terpanggil dan tertantang untuk turut membantu pemasyarakatan perangkat lunak yang bebas ini kepada masyarakat sambil mendidik masyarakat untuk tidak menggunakan perangkat lunak bajakan. Apapun dalihnya (misal harga software yang mahal) penggunaan perangkat lunak bajakan adalah tindakan melanggar hukum. Usaha pertama paling tidak kita sendiri harus membiasakan menggunakan perangkat lunak bebas. Seperti telah diuraikan di muka kita tak perlu khawatir jika perangkat lunak yang kita butuhkan tidak ada. Hampir semua perangkat lunak yang kita temukan di Windows dapat kita temukan padanannya di Linux. Masalahnya mau dan mampukah kita ? Rasa-rasanya kita mampu karena mempelajari Linux tidaklah sesulit yang dibayangkan orang. Apalagi distro-dsitro Linux yang ada terus memperbaiki diri untuk menawarkan berbagai kemudahan bagi penggunanya. Kemauan kita mungkin yang masih lemah karena kita sudah terbiasa mendapatkan perangkat lunak bajakan dengan mudah. Masalah lain yang juga tak kalah beratnya dalam pemasyarakatan GNU-Linux adalah kurang adanya dukungan dari para pengambil kebijaksanaan sehingga usahausaha pemasyarakatan seperti ini sering kali hanya lips service atau hanya berjalan di awal-wal saja sementara kontinuitasnya kedodoran.

Akhir kata penulis ingin mengajak pembaca untuk mulai menggunakan perangkat lunak bebas ini agar kita tak lagi tergantung pada pihak lain. Bagaimana bila suatu saat kantor kita dituntut oleh para vendor perangkat lunak karena kita menggunakan produk bajakan. Hal ini pastilah mencoreng muka kita. Sebagai awal dari ajakan ini, dan agar konsisten dengan apa yang penulis tulis di sini, penulis menggunakan Open.Office 1.0 yang berjalan di atas Debian GNU-Linux untuk menulis tulisan ini. Ternyata sangat mudah dan nyaman sebagaimana kita menggunakan Microsoft Words. Mau mencoba? 


\section{Referensi}

www.fsf.org

www.sourceforce.net

freshmeat.net

www.kde.org

www.gnome.org

www.debian.org

www.kernel.org

www.gimp.org

www.gnu.org 